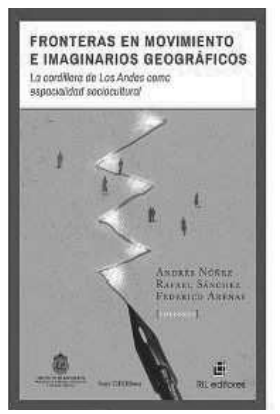

\title{
Andrés Núñez, Rafael Sánchez y Federico Arenas (editores). Fronteras en movimiento e imaginarios geográficos. La cordillera de los Andes como espacialidad sociocultural.
}

\author{
Santiago de Chile: serie GEOlibros $\mathrm{N}^{\circ} 17$, Instituto de \\ Geografía, Pontificia Universidad Católica de Chile / RIL \\ editores, 2013. $430 \mathrm{p}$.
}

\author{
Macarena Pérez García ${ }^{1}$
}

\begin{abstract}
Una geografía abierta a las ciencias sociales, capaz de dialogar con otros saberes para el estudio del espacio, poseedor de una producción cambiante y que se aleja de la concepción solo física, es lo que se expone en los distintos estudios realizados en torno a la cordillera de los Andes que conforman este libro.
\end{abstract}

Es esta cordillera, como frontera divisoria, la que marca para muchos un límite difuso al momento de comprender este espacio como una construcción social, en el que no siempre se considera por los habitantes el límite político-administrativo, como determinante para sus relaciones comerciales y sociales, sino que forma parte del cómo se vive, en constante contacto e interacción.

Se exponen a través de diversos trabajos de investigación realizados en Chile y Argentina en torno a la cordillera de los Andes, la concepción de los espacios fronterizos como espacios sociales, por tanto poseedores de dinámicas temporales y enmarcadas en una memoria colectiva. El espacio cordillerano, por tanto, visualizado en distintas épocas como en el caso expuesto por Jaime Flores en la Región de La Araucanía, ha sido una zona habitada desde tiempos ancestrales por

1 Instituto de Geografía, Pontificia Universidad Católica de Chile (Chile). E-mail: mperez1@uc.cl pueblos prehispánicos, poseedores de un gran conocimiento y activo desarrollo de comunidades que no reconocen este territorio como una frontera divisoria de sus relaciones comerciales y sociales.

Esta situación es también revisada en el caso de la investigación realizada por Laura Marcela Méndez y Jorge Muñoz, al estudiar la Compañía Comercial y Ganadera ChileArgentina, desarrollada en el denominado antiguo paso de Cochamó, en la Región de Los Lagos, que después de varios años de auge y entrega de avances tecnológicos a esta zona, ve su fin en torno a 1919 asociado a ideales nacionalistas, y conflictos limítrofes, que fomentan la apropiación de un territorio.

Sin duda los imaginarios asociados a la cordillera de los Andes, que forma parte del paisaje a lo largo de todo Chile, acompaña a cada habitante de este país en distinta medida durante toda su vida, siendo la formación escolar una primera aproximación a nociones conceptuales en la sala de clases.

Esta situación es estudiada por el geógrafo Abraham Paulsen a través de la revisión de textos escolares en Chile, en torno a cómo se expone la cordillera de los Andes y se construyen los discursos sobre esta. Como resultado de esta revisión surge la inquietud sobre la relevancia de visualizar este espacio como una zona de oportunidades para futuras gene- 
raciones, utilizando para llegar a esto dibujos de alumnos que permiten apreciar las diferencias en su imaginario y conceptualización. En esta misma línea el geógrafo chileno Fabián Araya, realiza una exploración de textos escolares de enseñanza básica y media para visualizar desde qué dimensión se expone la cordillera de los Andes al momento de abordar los contenidos curriculares, concluyendo en la necesidad de incorporar el estudio de este espacio como dinámico, y relevante desde el punto de vista medioambiental, y no solo como un límite físico.

La cordillera de los Andes en el norte de Chile, y su estudio de acuerdo a los autores chilenos Marcela Tapia y Cristian Ovando, en el marco de las nuevas relaciones sociales en la región fronteriza de Chile, Tarapacá en la última década del siglo XX, da cuenta de un problema de escala, entre una visión de zona global y conectada, con oportunidades de movilidad, y una escala nacional, orientada a la contención. También en el norte chileno, Sergio González, plantea en el estudio de la economía salitrera con el país vecino de Bolivia, una interesante visión en torno a la relación comercial entre los años 1870 y 1920, en que la frontera entre ambas naciones se visualiza como abierta y dinámica.

Teniendo en cuenta la importancia dada en el texto al comprender la geografía como parte de las ciencias sociales, se incorporan investigaciones de distintos saberes, siendo interesante relevar el estudio realizado por las antropólogas argentinas Carolina Crespo y María Alma Tozzini, sobre la Comarca Andina del paralelo $42^{\circ}$, en la Patagonia Argentina. En esta investigación se exponen las narrativas disímiles con respecto a las fronteras, ya sea desde la visión propia de un momento histórico, como de las relaciones interétnicas, que dan cuenta de desigualdades y redefiniciones relevantes. Se invisibilizan por tanto para las autoras, estas visiones por sobre las oficiales.

Para el también antropólogo argentino Diego Escolar, a través de su investigación en la zona de San Juan, se da cuenta de esta invisibilización de activos intercambios y movimientos de población por ejemplo de aborígenes, que tienen como escenario la cordillera de los Andes a través de la naturalización de la cordillera por parte de las autoridades de la nación.

\section{Reflexiones finales}

El libro aborda una temática vigente y que resulta esencial al momento de comprender los alcances de la geografía cultural en relación a las fronteras y sus múltiples interpretaciones. Este trabajo no solo da la oportunidad de exponer las investigaciones en relación a esto, sino que permite aunar esfuerzos para redescubrir un territorio poseedor de marcadas relaciones históricas con distintas naciones. Esto se plasma también en la investigación de Susana Bandieri, en la frontera argentino- chilena como espacio social en la Patagonia, dando cuenta de la relevancia de realizar estudios que aborden estos espacios más allá de los conceptos de Estado-nación, ya que esto reduce la importancia de las dinámicas sociales propias de estos territorios patagónicos.

Las nuevas fronteras emergen hoy a la luz de los avances tecnológicos e información disponible, pero ise realiza acaso al momento de estudiar estos territorios una lectura más allá de lo evidente? ¿Es abordado el estudio de este espacio considerado para muchos como una frontera física, incorporando a los habitantes que construyen el territorio? Este texto posee un valor agregado relacionado con el invitar a releer las fronteras desde una perspectiva espacial que incorpore la dimensión social y temporal como base. 